\title{
Brexit and Environmental Law: Challenges and Opportunities
}

Dr Eloise Scotford and Dr Megan Bowman, The Dickson Poon School of Law, King's

\section{College London}

This is an Accepted Manuscript of an article published by Taylor \& Francis in the

King's Law Journal on 9 December 2016, available online: http://www.tandfonline.com/doi/full/10.1080/09615768.2016.1258779

The prospect of the UK leaving the European Union poses significant challenges for UK environmental law. Fundamentally, this is because environmental issues, both legal and physical, cannot be hermetically sealed within a single jurisdiction. Environmental law is an inherently multi-jurisdictional and transnational enterprise, ${ }^{1}$ making the EU a highly competent regulatory actor in pursuing many environmental objectives. Initially, Brexit appears to pose mainly technical challenges for UK environmental law, but these challenges reflect more fundamental normative and institutional issues. There is a complex legal task ahead in translating and disaggregating an extensive and intricate EU environmental acquis into 'sovereign' UK environmental law.

Whilst the UK government has indicated that current EU law, including EU environmental law, will initially be 'converted' into domestic UK law by legal mechanisms introduced through a 'Great Repeal Bill', ${ }^{2}$ this apparently simple technical manoeuvre raises at least three problems. ${ }^{3}$ First, there will need to be new

\footnotetext{
${ }^{1}$ Liz Fisher and James Harrison, 'Beyond the Binary: Brexit, Environmental Law, and an Interconnected World’ (OUPBlog 2016), available at http://blog.oup.com/2016/09/binary-brexitenvironmental-law/ (accessed 22 October 2016).

${ }^{2}$ David Davis, 'Exiting the EU Next Steps: Ministerial Statement 10 October 2016' (oral statement to Parliament delivered 10 October 2016).

${ }^{3}$ As has since been acknowledged by the Secretary of State for Environment, Food and Rural affairs (around one third of environmental legislation 'won't be easy to transpose'): Environmental Audit Committee, 'Future of the Natural Environment after the EU Referendum', evidence session 25 October 2016, testimony of the Rt Hon Andrea Leadsom MP.
} 
UK legislation translating substantive provisions of directly applicable EU regulations, such as the Waste Shipment Regulation and $\mathrm{REACH},{ }^{4}$ which set out regulatory provisions that are relied upon by operators in the waste and chemicals industries. Whilst the $\mathrm{UK}$ is a member of the EU, these provisions do not require domestic legislation to operate as binding UK law. Thus, a risk now looms of considerable regulatory uncertainty for business without new domestic legislation in these areas. Second, there are significant questions concerning the interpretation and enforcement of 'preserved' EU law, and the nature of the UK governance frameworks that will support it. For example, will pre- and post-Brexit CJEU judgments continue to be relevant sources of interpretation for EU provisions that are converted into domestic UK law? What of the doctrine of direct effect that has given UK citizens the right to hold the government to account for failing to comply with key EU environmental obligations (demonstrated notably in UK litigation concerning breaches of EU air quality law) $?^{5}$ More generally, the very existence of binding EU legislation, supported by the enforcement powers of the Commission, has held the government to environmental standards, targets and obligations that characterize much of the EU environmental acquis. ${ }^{6}$ How will the government be held to account for meeting such standards and obligations in the future, whether in relation to air and water quality standards, renewable energy targets, or special areas of conservation? Beyond such legal targets and required environmental outcomes, Maria Lee shows how EU environmental frameworks have constructed a rich governance framework

\footnotetext{
${ }^{4}$ Regulation 1013/2006/EC on shipments of waste [2006] L190/1; Regulation 1907/2006/EC concerning the Registration, Evaluation, Authorisation and Restriction of Chemicals (REACH) [2006] OJ L396/1.

${ }^{5}$ Case C-404/13 R(ClientEarth) v Secretary of State for the Environment, Food and Rural Affairs [2014] ECLI:EU:C:2014:2382, especially [54].

${ }^{6}$ This was notably highlighted in the second successful ClientEarth judicial review challenge to the UK government's air quality plans, which were found to have failed to establish adequate mechanisms for bringing the UK into compliance with EU air quality standards in the 'shortest possible time': ClientEarth (No 2) v Secretary of State for the Environment, Food and Rural Affairs [2016] EWHC 2740 .
} 
for environmental law. This is particularly through Member State accountability mechanisms such as 'planning, reporting and explaining requirements'. ${ }^{7}$ How such environmental accountability might be maintained in UK domestic law after legal separation from the EU will require careful thought, deliberation and institutionbuilding. This again involves much more work than simply rewriting EU legislative provisions into domestic UK law.

The third concern with the supposedly simple legislative conversion of EU environmental law into UK law is that of transparency. There are already serious issues of legislative transparency in relation to UK environmental legislation that has been transposed from EU law via secondary legislation. This is problematic in rule of law terms, ${ }^{8}$ but a technical 'dumping' or 'hiding' of key environment law obligations in secondary legislation for the sake of a legally expedient Brexit process would only heighten these concerns, and would also limit the role of Parliament in any future amendments of UK environmental law. This legislative concern exposes, in a very real and pragmatic sense, the normative tensions that will create vulnerabilities for some areas of environmental law post-Brexit. Sustainability imperatives such as clean air and the protection of habitats are sometimes presented as barriers to economic development. The constraining impact of EU air quality standards for airport expansion at Heathrow is a prime example, particularly in light of the government's recently expressed support for this scheme despite air quality in Heathrow and surrounding local areas currently breaching legal limits for levels of nitrogen dioxide in the ambient air. The strong level of protection in these areas

\footnotetext{
${ }^{7}$ Maria Lee, 'Brexit: Environmental Accountability and EU Governance' (OUPBlog 2016), available at http://blog.oup.com/2016/10/brexit-environment-eu-governance/ (accessed 22 October 2016).

${ }^{8}$ UKELA, KCL and BRASS, 'The State of UK Environmental Law in 2011-2012: Is There a Case for Legislative Reform?' (2012), available at https://www.ukela.org/content/page/3006/Final\%20report\%20UK\%20Environmental\%20Law\%20in\% 202011-2012.pdf (accessed 24 October 2014).
} 
under EU law may become vulnerable to policy trade-offs once under UK sovereign control. This concern is only heightened in the context of transparency, particularly if there is limited Parliamentary oversight of proposed legislative amendments that effectively weaken environmental standards or diminish avenues for their enforcement by interested citizens. ${ }^{9}$

However, if the UK government can resist making compromises in relation to environmental protection, promising opportunities for UK environmental law postBrexit are emerging. Climate change law and governance provides an interesting case for potential positive development. In this area, as in others areas of environmental law, ${ }^{10}$ the UK has provided leadership for EU environmental law and policy. ${ }^{11}$ Initial signs since the June 2016 UK referendum vote suggest this leadership role can continue. A week after the vote, the Government accepted the fifth carbon budget of the Committee on Climate Change, fulfilling its long-term policy setting obligations under the Climate Change Act 2008. And whilst the recent merging of the Department of Energy and Climate Change with the Department for Business (to create the Department for Business, Energy and Industrial Strategy) has caused concern about the dilution of environmental responsibility by a post-Brexit government, this institutional (re)coupling may present new opportunities for UK climate change policy. In particular, it provides a governmental structure for mainstreaming climate change policy within core economic policy areas. Despite concerns that we could lose the input of EU climate regulatory schemes in achieving

\footnotetext{
${ }^{9}$ See Eloise Scotford, 'UK Air Quality Law at a Crossroads' (OUPBlog 2016), available at http://blog.oup.com/2016/10/air-quality-law-environment/ (accessed 24 October 2016)

${ }^{10} \mathrm{Eg}$ the EU scheme for integrated pollution control of heavily polluting industrial plants (Directive 2010/75/EU on industrial emissions (integrated pollution prevention and control [2010] OJ L334/17) was originally inspired by a scheme for integrated pollution control previously established in the UK (Environmental Protection Act 1990, pt 1).

${ }^{11}$ This is particularly seen in the Climate Change Act 2008.
} 
our domestic carbon budgets, ${ }^{12}$ this kind of governmental adjustment provides institutional space for innovative UK climate governance, which is not available at the EU level with its domains of siloed policy competence. This kind of policy integration is supported by recent interventions by Mark Carney of the Bank of England and the Financial Stability Board, identifying climate change as both a risk and an opportunity for systemic financial stability, ${ }^{13}$ thereby encouraging innovation in green finance and the corporate and financial regulation that facilitates it. Despite government support for this direction of travel, ${ }^{14}$ there remains much work to be done in mainstreaming 'green' financial innovations in both the UK and wider G20. ${ }^{15}$ This is an area of post-Brexit environmental governance in which the UK government has a regulatory opportunity, backed by strong financial market signals and the recent ratification of the Paris Agreement, ${ }^{16}$ to mainstream UK economic activity in line with its own statutory carbon budgets to support the transition to a low-carbon economy.

In short, a post-Brexit landscape presents challenges but also opportunities for the UK government in the realm of environmental law. Most notably, and if the UK Government is willing, it could provide impetus for the government to tidy up its domestic statute book of fragmented and opaque environmental legislation, to integrate domestic policies to pursue an ambitious national and global climate

\footnotetext{
${ }^{12}$ Climate Change Committee, 'Meeting Carbon Budgets - Implications of Brexit for UK Climate Policy' (October 2016), available at https://www.theccc.org.uk/publication/meeting-carbon-budgetsimplications-of-brexit-for-uk-climate-policy/ (accessed 24 October 2016).

${ }^{13}$ Bank of England, 'Breaking the Tragedy of the Horizon - Climate Change and Financial Stability' (speech given at Lloyd's of London, 29 September 2016), available at http://www.bankofengland.co.uk/publications/Documents/speeches/2015/speech844.pdf (accessed 24 October 2016).

14 'Brexit Gives Boost to UK Treasury's Focus on Green Finance' (Bloomberg, 14 September 2016), available at www.bloomberg.com/news/articles/2016-09-14/brexit-gives-boost-to-u-k-treasury-s-focuson-green-finance (accessed 24 October 2016).

${ }^{15}$ Megan Bowman, Banking on Climate Change: How Finance Actors and Transnational Regulatory Regimes Are Responding (Kluwer 2015); Cambridge Centre for Sustainable Finance, Environmental Risk Analysis by Financial Institutions: A Review of Global Practice (UNEP 2016).

${ }^{16}$ The Paris Agreement on Climate Change, signed on 22 April 2016, came into force on 4 November 2016.
} 
regulatory agenda, and to engage the British public in informed debate about how environmental protection and wellbeing goals are best set and enforced in a UK context. At the same time, the UK would need to develop a body of domestic environmental law that accommodates different levels of governance locally, transnationally, and internationally. This is particularly salient in light of devolved UK environmental law (which is increasingly progressive in Wales and Scotland), our interconnected natural environment with our European neighbours, increasingly 'green' global financial markets, and the international environmental agreements to which we are subject. 